\title{
胃癌の組織化学的, 電子顕微鏡的研究
}

\author{
第 3 編
}

大腺腔型及び乳嘴型腺癌の微細構造

岡山大学医学部田中外科（主任：田中早苗）

津田博文

〔昭和 45 年 11 月 18 日受稿〕

内容目次

\section{第 1 章 緒 言 \\ 第 2 章 実験材料と方法 \\ 第 3 章 実験成樍 \\ I 大腺腔型の電䫓的所見}

\section{第 1 章 緒吉}

第 1 編では胃癌の単純癌について，第 2 編では小 腺腔型について述べたか，本編では大腺腔型及び乳 嘴型について記載する。

\section{第 2 章 実酫材料と方法}

第 1 編並びに第 2 編に同じ.

\section{第3章 実 医 成 繶}

\section{I 大腺望型の電顕的所見}

光顕的に大きな類円形の腺腔を認め, 腺癌として の特徵が明膫となり, 細胞数20ケ以上（但し腺腔横 断面の細胞数) の大腺腔で，且つ乳嘴型でないすの 之定義する. 即ち tight junction, intermediate junction が明瞭代認められ， desmosome も細胞全周にほ 法均等江発達して, 遊離腺腔, 遊離細胞索, 遊離細 胞が極めて少なくなる．細胞形も上皮系由来として の特徽があらわ机，立方形乃至短円柱形である. basementmembrane あ発達して腺腔としての特徽か 更に明瞭之なつてくる，microvilli б全細胞に平均 に発達して，極性が明らかである．粘液顆粒は胞体 内化少なくなるが, glycogen 顆粒の集碃像をみるの あ特徽である。

(1) 細胞の配列：単首配列もみるが，多くは 2〜 3 首化重層配列しているととが多い，腺腔の大きさ は細胞数20ケ以上（但し腺腔横断面での細胞数）加
II 乳嘴型の電顕的所見

III 大腺腔型並びに乳嘴型の組織化学的所見

第 4 章 考 按

第 5 章 結 論

ら成り，類円形であることが多い，又遊離腺腔，遊 離細胞索，遊離細胞等をみるととが極めて少ない。

(2) 細胞形：短円柱形乃至立方形を主体として, 長円柱形，扁平細胞むみられる：同一腺腔内に種々 の形の細胞が混在しているととが多い.

(8) 核：核膜の弯入はやや小腺腔型に比して少な く，類円形核す少数みられる，胞体の中央に位置す るととが多く，極性が未だ明確でない．

(4) 細胞接合面：tight junction, intermediate junction が明瞭汇認められる。, desmosomeは細胞全 周に均等に発達して (写真 1), 周囲の細胞之強固 亿接合して遊離傾向が少ない，それ故 intercellular space あ極めて㹨くなるが，成熟胃腺細胞のそれに 比較するとやはり相当広い症例が多い．

(5) 分泌細管形成：全症例中 $25 \%$ の症例飞大腺膑 を構成している細胞内に分泌細管が極く少数含まれ ていた。

(6) Basementmembrane : 全症例中 30 96亿形成さ れていたが，完全であることは少なく，腺腔の一部 で欠損しているととが多い。

(7) 腺腔面：腺腔に面する細胞表面は平坦である ことが多く，時に凸面を形成していることがある。 全細胞に平均して microvilli の発育もよいととが多 い. microvilli の少数の細胞乃至短少の microvilli $に$ 於いても filament の発育は極めてよい，小腸上皮 に類似した striated border (写真 2), terminal web がみられるとともある. microvilli の極性は明確と 
なり，間質面に向つてみられるてとは全くなくな る. 11例中 1 例化 apocrine secretion の像 (㝍真 3) がみられ、アポクリン突起内に少数の granular endoplasmic reticulum が含またているのが観察され た.

(B) Golgi 装置之粘液顆柆：Golgi 装置は中等度に 発達して核上部に位置し，極性が明らかであるが， 小腺腔型に比して発育はやや悪い，粘液顆柆もはる 加に少なく，管腔面に少数みられるととが多く， Golgi 野にみるととが少はい. 顆粒の電子密度は種 々のあのがみられるが，同一症例ではほは一定して いることが多い，粘液顆粒の大きさ，形む成就胃腺 細胞にみられるすのに類似したものが多くなり，粘 液顆粒の内部構造む均一なるのが多い.

Q. Glycogen 顆粒 (写真 4)：約 50\%の症例では 核上部，核下部に Glycogen 顆粒の集皘像がみられ た. glycogen 顆粒认は電子密度の極めて高いあの と,やや低いあのの二種類あるととが観察された.

(10) Mitochondria：発育は全般的によいが, 空胞 変性像は極めて少ない。

(19) Free ribosome と granul ar endoplasmic reticulum : granular endoplasmic reticulum $屯$ 多く, free ribosome क多い.

(1.) Lysosome: secondary lysosome の形でろられ るが, 数は少ない.

附

大腺腔型之印環状癌細胞について

大腺腔型で印環状癌細胞をみることは極めて少な く，11例中 1 例に印噮状癌細胞 I型がみられたにす ぎない，乙の1例は大腺腔を構成している細胞に多 数認められたもので，その他多数の分泌細管も同時 に観察された。

\section{II 勫型の奄䫓的所見}

細胞数20ケ以上（但し腺腔横断面での細胞数とす る）の大腺腔で，しかむ問質が乳嘴状に增殖してい る型でする.電顕的には tight junction, intermediate junction, basementmembrane 汃胃癌中最もよく発達 して, 遊離傾向は認められない，又細胞形す成熟胃 腺細胞に類似して円柱形のものが多くはり，一見し て上皮系由来であるととが明確となる，核の極性も 明らかて，類円形乃至椅円形で小型の核加多く，核 小体も小さいあのが多い.

(1) 練胞の配列：2 3 層に重層配列していると 之が多い，遊離腺腔，逰離細胞索，遊離細胞は認め
られない．腺腔活細胞数20ケ以上（但し腺腔横断面 での細胞数とする)の大腺腔で間質が乳嘴状に增殖 している.

(2) 細胞形 (写真 5): 短円柱形乃至長円柱形細 胞が主体をなし，立方形細胞が混在しているととも ある。

(3) 核：短円柱形乃至長円柱形の核をみることが 多くなる. 小形で核膜の驾入の少ない類円形核も 多い，核小体す小形であることが多く，核は基底部 に位置して極性を示している.

(4) 細胞接合面： tight junction, intermediate junction， desmosome は胃癌中最むよく発達してい る. intercellular space は成熟胃腺細胞に類似して 極めて狭い症例も多くなる。

(5) 分泌細管形成：全く観察されない.

(6) Basementmembrane : 全症例に認められるが, その中50\%の症例では部分的に欠損していた。

(7) 腺腔面：腺腔に面する細胞表面は50\%の症例 では円蓋状に突出しており，残り $50 \%$ \%は平坦であ る. microvilliの発育は大腺腔江類似してよいものか 多い. 又50\%の症例では, apocrine secretion 像 (写 真6）がみられ。アポクリン突起内に少数の free ribosome が観察された.

(8) Golgi 装置と阽液顆粒：Golgi 装置は中等度 に発達して，極性が明らかである，粘液顆粒は殆ん ど胞体内に認められない，時に管腔面に少数みられ るととがあるが，Golgi 野には認められない，粘液 顆粒の大きさ，形，電子密度等は大腺腔型に類似し ている.

(9) Glycogen 顆粒 : Glycogen 顆粒の集積像は観 察されなかつた。

(10) Mitochondria：大腺腔型に類似してよく発達 している，mitochondria が核上部に集積して極性を 示しているととがある.

(ii) Free ribosome $\&$ granular endoplasmic reticulum : 一般に free ribosome は多く，granular endoplasmic reticulum は発達している。し加し胃腺主細 胞の如く発達していることは極めて稀である：時に 核上部に free ribosome の集皘像（写真 7) がみら れる。

(12) Lysosome: lysosome は少なく, /secondary lyвоmeが稀に認められる。

\section{III 大腺腔型並びに釈嘴型の組織化学的所見}

粘液の性状（表 1，2）では，大腺腔型に於いて 
は.PAS 染色のみ陽性を示す例が多い点が特徽的で あり, 乳整型では alcian blue, PAS 染色共飞陽性 を示すのが全例である．粘液陰性例は 1 例すみられ はい，粘液の分布（表 3，4）では，大腺腔型に於 いては，管腔内にのみ粘液が認められ，そ机を構成

表 1 大腺釷型の粘液性状 (Alcian blue (AB) -PAS 重染色)

\begin{tabular}{l|c|c|c|c}
\hline 粘液の性状 & $\begin{array}{c}\mathrm{AB}+ \\
\mathrm{PAS}-\end{array}$ & $\begin{array}{c}\mathrm{AB}+ \\
\mathrm{PAS}+\end{array}$ & $\begin{array}{c}\mathrm{AB}- \\
\mathrm{PAS}+\end{array}$ & $\begin{array}{c}\mathrm{AB}- \\
\mathrm{PAS}-\end{array}$ \\
\hline 例 ${ }^{2}$ & 0 & 3 & 4 & 0 \\
& 0 & 43 & 57 & 0
\end{tabular}

表 2 乳㗪型の粘液性状

\begin{tabular}{|c|c|c|c|c|}
\hline 粘液の性状。 & $\begin{array}{l}\text { AB+ } \\
\text { PAS- }\end{array}$ & $\begin{array}{l}\text { AB+ } \\
\text { PAS+ }\end{array}$ & $\underset{\text { PAS+ }}{A B-}$ & $\underset{\text { PAS- }}{\mathrm{AB}-}$ \\
\hline 例 数 & 0 & 3 & 0 & 0 \\
\hline 96 & 0 & 100 & 0 & 0 \\
\hline
\end{tabular}

表 3 大腺整型の粘液分布 (Alcian blue (AB) -PAS 重染色)

\begin{tabular}{|c|c|c|c|c|}
\hline 粘液の分布 & $\begin{array}{l}\text { 暍体十 } \\
\text { 管腔一 }\end{array}$ & $\begin{array}{l}\text { 暍体+ } \\
\text { 管腔十 }\end{array}$ & $\begin{array}{l}\text { 盷体一 } \\
\text { 管腔＋ }\end{array}$ & 胞体一 \\
\hline 例 数 & 0 & 3 & 4 & 0 \\
\hline$\%$ & 0 & 43 & 57 & 0 \\
\hline
\end{tabular}

表 4 乳嘴型の粘液分布

\begin{tabular}{|c|c|c|c|c|}
\hline 粘液の分布 & $\begin{array}{l}\text { 暍体十 } \\
\text { 管腔一 }\end{array}$ & $\begin{array}{l}\text { 暍体+ } \\
\text { 管腔十 }\end{array}$ & $\begin{array}{l}\text { 盷体一 } \\
\text { 管腔十 }\end{array}$ & $\begin{array}{l}\text { 暍体一 } \\
\text { 管腔一 }\end{array}$ \\
\hline 例 数 & 0 & 0 & 3 & 0 \\
\hline 96 & 0 & 0 & 100 & 0 \\
\hline
\end{tabular}

表 5 大腺腔型及び乳嘴型のアミノベプチ ダーゼ染色

\begin{tabular}{|c|c|c|}
\hline アミノヘフチダーぜ & + & - \\
\hline 例 & 5 & 4 \\
\hline 95 & 56 & 44 \\
\hline
\end{tabular}

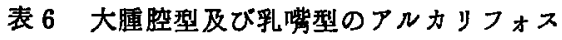
フアターゼ染色

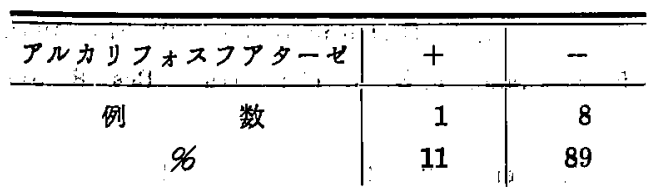

している細胞内に粘液がみられない症例が多い。と の傾向は更に乳嘴型で極端に強くなり，全例が管腔

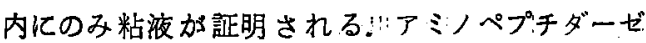
（表 5)，アルカリフォスファターゼ（表 6）染色で は陽性例は小腺腔型，単純癌とほぼ同頻度である。

\section{第 4 章 考 按}

大腺腔型，乳嘴型共に小腺腔型に比して，細胞形， tight junction, intermediate junction; desmosome 等の細胞表面構造, 細胞の極性 (細胞形, 核, Golgi 装置，microvilli，粘液分布等に関する)，Golgi 装 置, mitochondria, granular endoplesmic reticulum 等は分化しているが, 粘液産生能, free ribosome $に$ 関してはかなり未分化である，又核，核小体は単純 癌，小腺腔型と大差がみられない，microvilli では filament の発育が極めてよく，小腸上皮の microvilli に類似して分化の混乱を示している. 大腺腔型と乳 嘴型の相違点は種々みられるが，特徴的な点は乳嘴 型の方が核の分化度か高くなつていることである。 即ち核の極性の出現，小形で類円形乃至楕队形の 核, 小形の核小体等，一般癌細胞核の特質がみられ はい核が多い，河原りによれば円柱上皮癌ては核膜 の弯入の少ない核加多いと報告しているととと二致 している.乳鄨型は胃癌中細胞内微細構造上種々の 点で最す分化度が高くなるが，転移形成，mitosis， 核細胞質増大等一般癌細胞の特性を有しているが, 電顕的に成熟胃腺粘液細胞と比較すると次のような 相達点汃みられる。

(1) 成熟胃腺粘液細胞は単層配列であるが，乳喘 型では重層配列が多い，又乳嘴型の腺腔は不整形で 大きい.

(2) 細胞形については成熟胃腺粘液細胞では全て 一様に長円柱形であるのに対して，乳嘴型では長円 柱形の他, 短队柱形, 立方形等種々の形がみられる。

(3) 乳嘴型の desmosome は不完全な形態を示して いることがある。即ち desmosome が相接している 片側の細胞にしかみられないとか, desmosome の filament が極めて少ない等の所見が観察される。

(4) 乳嘴型の intercellular space は狭くなつてい るか，成熟胃腺粘液細胞の如く，消失する程狭いこ とは稀である。

(5) 乳啃型では microvilli の発達は極めてよく， 時に striated border としてみられる，又 microvilli の filament の発達が極めてよく, terminal web が みられ，正常胃腺粘液細胞之著しく異なつている。 
乳嘴型の microvilli は成熟胃腺粘液細胞よりむしろ, 小腸の absorptive cell2) 7) 乃至 undifferentiated crypt cell の microvilli に類似しており, 分化の方 向の異常を示している.

(6) Basementmembrane の形成が乳嘴型では完全 でな。

(7) 乳嘴型では apocrine secretion の像8) 11)を みるととがある. apocrine secretionは小腸の undifferentiated crypt cell (Trier12)13)) 乃至胃腺の壁 細胞（黒住14）でみられることが報告されている.

(8)胞体内粘液顆粒は乳嘴型ては成熟胃腺粘液細 胞に此して極めて少なく，粘液顆粒の大きさ, 形, 電子密度についてあ成熟胃腺粘液細胞に比較すると 未だ均一でない.

(9) Golgi 装置の発達は成剠胃腺粘液細胞に比較 すると重く, 症例により, 又同一症例でも各癌細胞 によつてその発䏍が均一でない.

(10) 拜嘴型では mitochondria, granular endoplasmic reticum の発達はよく, 成熟胃腺粘液細胞に比 して大差がみられないが, mitochondria が核上部に 集皘して極性がみら扎たり（との現象は胎児胃腺原 細胞乃至小腸の undifferentiated crypt cell でみら れる)，各症例，各細胞毎に 相当変化に富んでいる 点が異なる。

(11) 乳哮型は成熟胃腺粘液細胞に比し，はるかに free ribosome は多く, free ribosome 同様核上部に集積しているととがある。

(12) 成熟胃腺粘液細胞の核は円柱形，弯入は比較 的強いか，核小体は小さく，クロマチンの疑集も少 ない. 乳嘴型では核膜の弯入，クロマチンの凝集等 が強く，核小体が大きく，時に数ケ認められる.

(18) 乳㗪型では dark cell, secondary lysoso meか 成熟胃腺粘液細胞に比較すると多い。

次に組織化学的面より大腺腔型, 乳嘴型を考擦す ると，小腺腔型に比して粘液量は減少している．粘 液の分布它胞体内より管腔内にみられることが多 く，乳嘴型ては全例管腔内にしか粘液が分布してい ない. 大腺腔型，乳嘴型ては胞体内に粘液がみられ てむ，多くは腺腔に面する胞体表面に粘液が証明さ

文

1) 河原和夫：米子医誌，10：1222，1959.

2) Shawdunn, J: J. Anat. 101: 57, 1967.

3) Bonneville, M. A : J. Cell. Biol. $44: 151$, 1970 .
れることが多い，冒癌全体について云えることであ るが，成熟胃腺粘液細胞と異なり，癌細胞では産生 された粘液顆粒はすみやかに管膑内に排泄される 為, 胞体内に粘液が陰性の場合でも，管腔内には粘 液晹性のことが多い. 酵素活性では単純癌, 小腺腔 型に比较して著明な差はなく，てのことは間接的に microvilli の発達が同一であることを示している。

このように粘液産生能に関しては大腺腔型，乳嘴 型は小腺腔型より分化度が低くなつているが，醉素 活性については分化度に差が認められない。

第 5 章 結論

大腺腔型, 乳㗪型胃癌を組織化学的, 電顕的に検 索し，以下のような結論に達した。

1）乳嘴型と大腺腔型は tight junction, intermediate junction, desmosome, microvilli. Golgi 装置 等については大差がみられないが，細胞形，核， basementmembrane 等については乳嘴型はより分化 し，細胞形，核に関する極性る明確となる，又乳哓 型は大腺腔型より更に胞体内の粘液が少なくなる。

2) 両者共 $K$ tight junction, intermediate junction, desmosome, basementmembrane の発達加極め てよくなる為に遊離傾向は極めて少ない。

3）乳㗪型では一般癌細胞核の特質を失つた核が 多くみられる.

4）粘液顆粒は胞体内より腺腔内にみることか子多 く，Golgi 装置の発育は単純癌と小腺腔型の中問に 位置する。

5) Mitochondria, free ribosome, granular endoplasmic reticulum の発達は単純痹，小腺膑型と大差 がみられない。

(6) 粘液産生能は小腺腔型より低下しているが， 酵素活性では単純癌，小腺腔型との間に差がない。

擱筆するに当り御指導御校閲を睗わつた田中早苗 教授立び緒方卓郎講師に深甚の謝意を表すると共 飞実験材料を賜わつた岡山闵生会病院間野清志先生 に厚く感謝する，な括電顕撮影飞御協力下さつた 林，才原技官に深謝します。

献

4) Trier, J. S: Gastroenterology. $49: 574,1965$.

5) Sjöstrand, F. S: J. ultra struct. Res. $8: 517$, 1963.

6) Mukherjee, T. M : J. Cell. Biol. $34: 447$, 
1967.

7) Overton, J : J. Cell. Biol. $21: 75,1964$.

8) 黒住一昌 : Arch. hist. jap. 16:523, 1959.

9）川端五十鈴 : Arch. hist. jap. 25 : 165, 1964.

10) Kenjiro Yasuda : Fol. anat. jap. $38: 455,1962$.
11) 関根通失：日本組織学記録, $26: 281$, 昭 41 .

12) Trier, J. S : J. Cell. Biol, $18: 599,1963$.

13) Trier, J. S : Gastroenterology. $47: 480,1964$.

14）黒住一昌：Arch. hist. jap. 15 : 587, 1958.

\title{
写真 説 明
}

写真 1 : 大腺㚙型電顕像，胞体内には粘液顆粒は殆んどみられず. tiht junction, intermediate juction, desmosome が良く発達している。 $\times 12,000$

写真 2 : microvilli の上く発達している大腺腔型の電顕像。 $\times 10,000$

写真 3 ： 大腺腔型にみられた arocrine secretion の電顕像，細胞膜は microvilli の filament より制離して管 腔内に突出している。 $\times 10,000$

写真 4: 大腺腔型飞みられた glycogen の核上部集皘の電影像。 $\times 28,000$

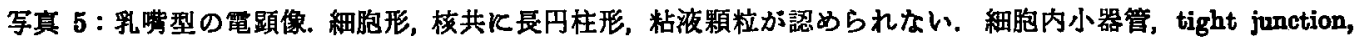
intermediatejunction, desmosome むよく発達しており，校の極性も明瞭である。 $\times 6,000$

写真6：乳䌘型てみられた arocrine secretion の電颢像。 $\times 9,800$

写真7：Free ribosomeの核上部集積を示す電顥像 (乳嘈型)。 $\times 30,000$

\section{A histochemical and electron microscopic studies of of the human stomach cancer.}

\author{
Part I, II and III.
}

\section{Hirobumi TSUDA}

\author{
Department of Surgery, Okayama Univeraity Medical School, Okayama
}

(Director: Prof. S. Tanaka)

A histochemical and electron microscopic studies of 48 cases of human stomach cancers were made and the following results were obtained.

1) According to their cytological features, the stomach cancers were classified into following types, 1) Papillary adenocarcinoma, and adenocarcinoma with large tubules, 2) Adenocarcinomawith small tubules, 3) Carcinoma simplex (subdivided mucocellular type, microvilli type, funiculus type, surface convex type, surface projection type and embryonal type.) The differences of differentiation of plasma membrane was very marked in these groupes, but those of cell organellas are less marked.

2) Production of the mucous is most prominent in adenocarcinoma with small tubules.

3) The some relationship between the aminopeptidase or alkalin phosphatase positive type cancer and their ultrastructural features aro observed. 


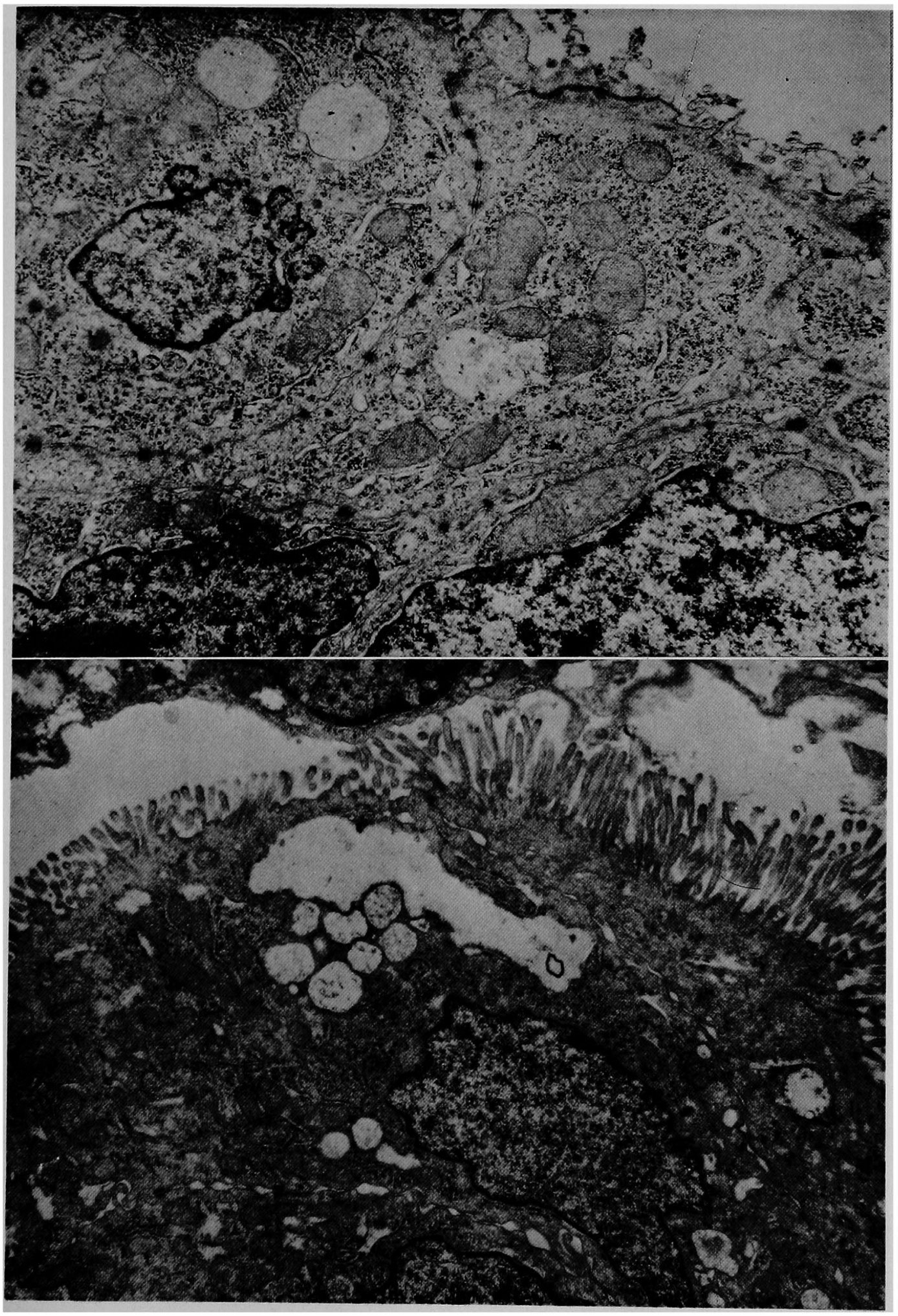




\section{津田論文附図}

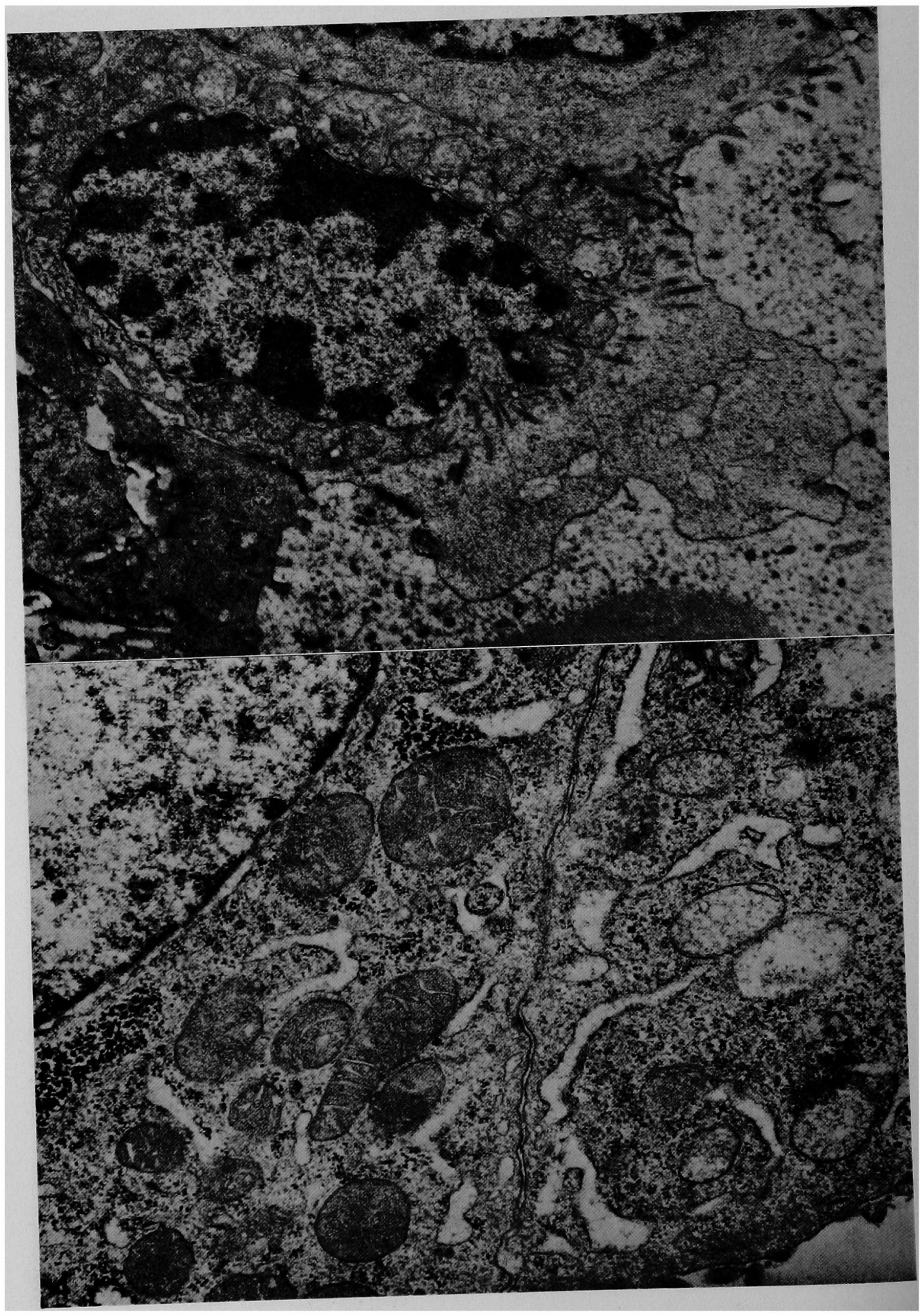




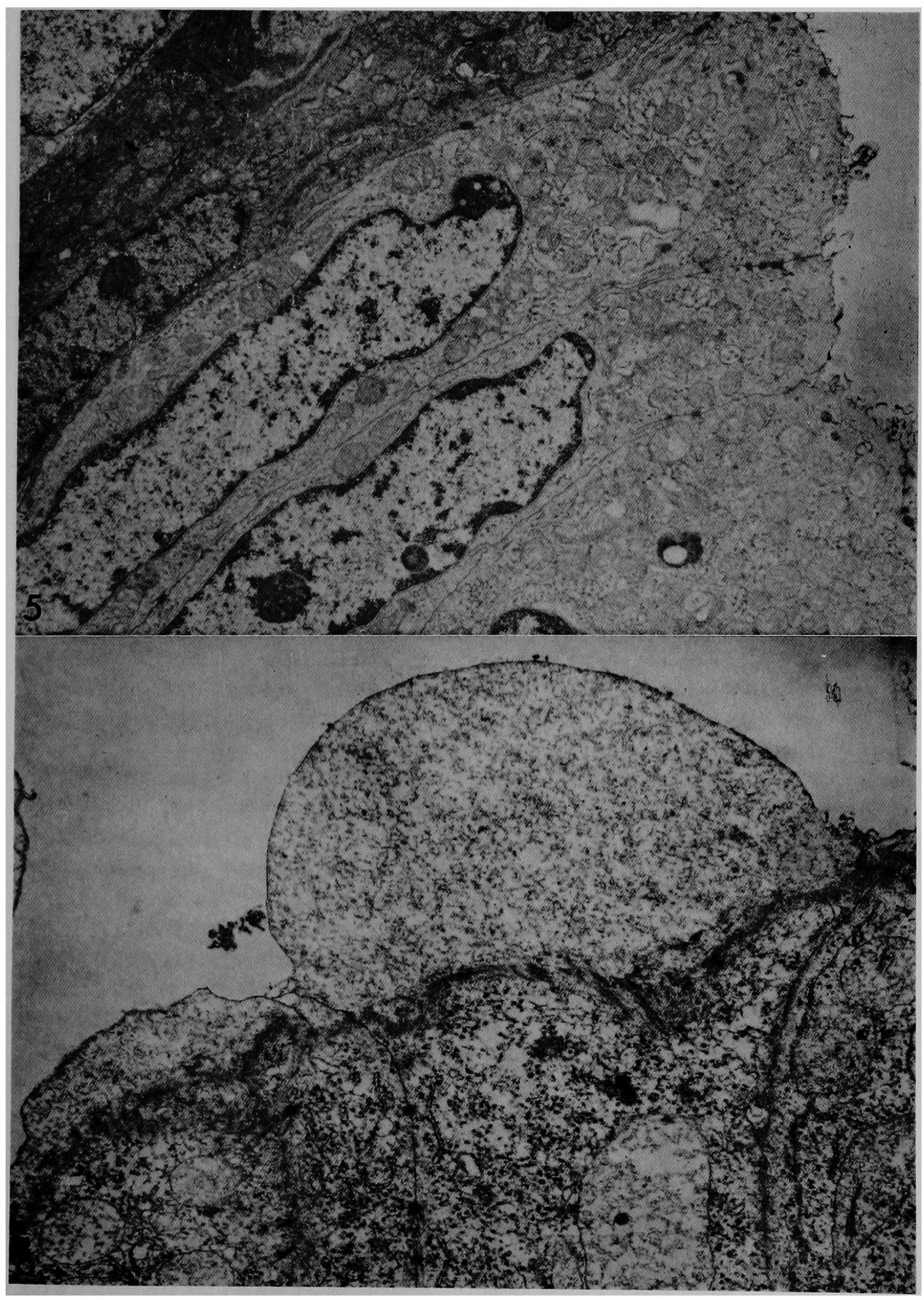




\section{津田論文附図}

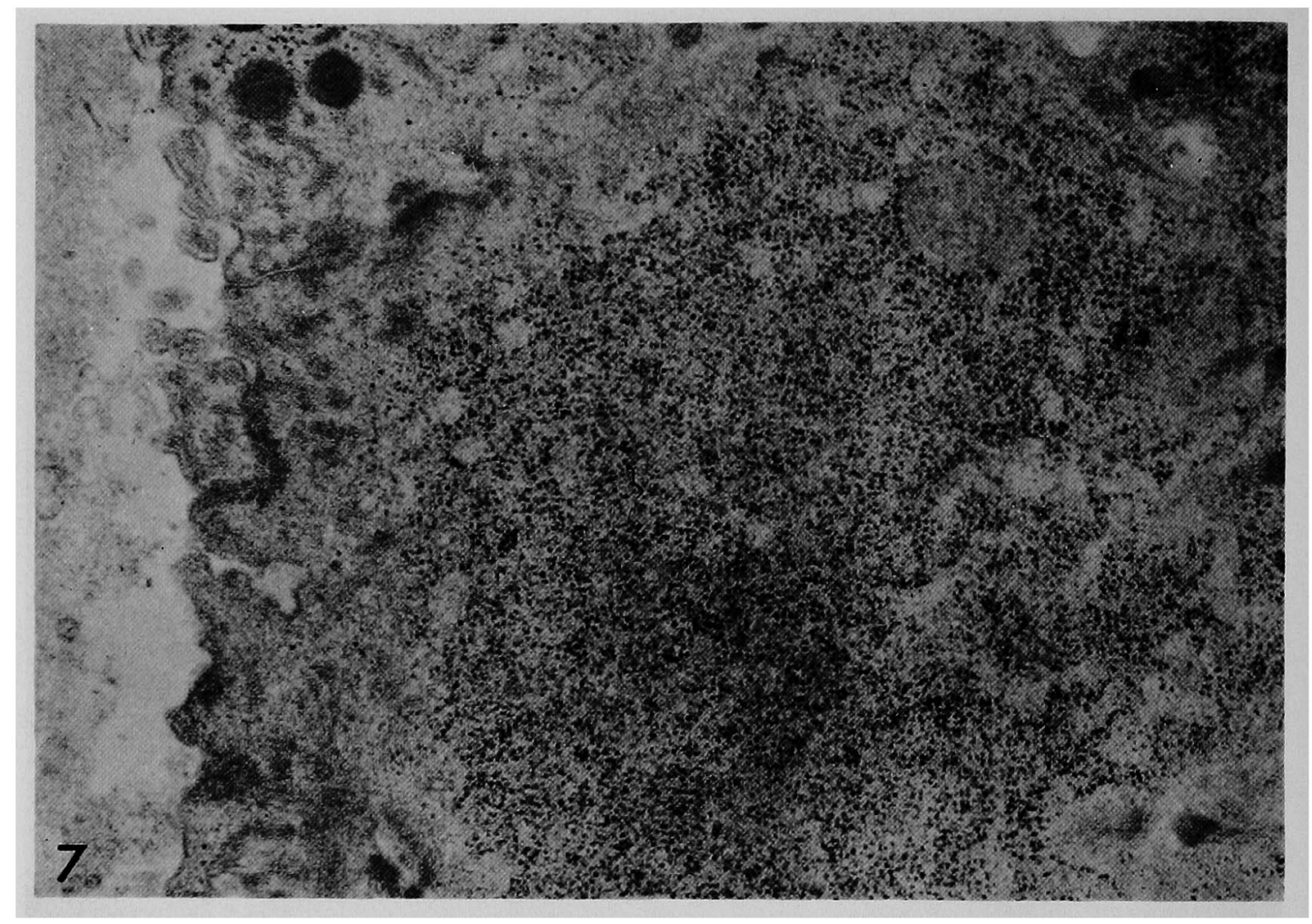

